\title{
Birds and mammals off the northern coast of Argentina: first report of an association between birds and a feeding Pygmy Right Whale Caprea marginata
}

\author{
Fåglar och däggdjur utanför Argentinas norra kust: första rapporten om fåglar \\ födosökande tillsammans med dvärgrätval Caprea marginata
}

HENRIK KYLIN

\begin{abstract}
When the icebreaker Oden passed between $39^{\circ} 36^{\prime} \mathrm{S}$, $57^{\circ} 46^{\prime} \mathrm{W}$ and $39^{\circ} 59^{\prime} \mathrm{S}, 58^{\circ} 11^{\prime} \mathrm{W}$ on 20 November 2007 , an extraordinary observation was made. A feeding Pygmy Right Whale Caprea marginata, a species rarely seen, was attended by eight Grey Phalaropes Phalaropus fulicarius, two Slender-billed Prions Pachyptila belcheri, and four Wilson's Storm Petrels Oceanites oceanicus. The birds returned to feed around the head of the whale every time it surfaced, presumably copepod plankton straining out between the baleen. The site is off Rio de la Plata estuary where nutrient rich freshwater meets cold water of the Malvinas (Falkland) Current, creating a hotspot with high levels of plankton food. The condi-

tions were extraordinarily favourable for observation with a calm sea, no wind and only a very weak swell. Six multispecies feeding groups were seen with a total of 42 species of birds, eleven species of whales, dolphins and porpoises, and three species of seals. Dusky Dolphins Lagenorhynchus obscurus and Great Shearwaters Puffinus gravis were predominant in the groups.

Henrik Kylin, Norwegian Institute for Air Research, Fram Centre, NO-9296 Tromsø, Norway and Department of Water and Environmental Studies, Linköping University, SE-581 83 Linköping, Sweden.

henrik.kylin@liu.se
\end{abstract}

Received 22 March 2013, Accepted 1 August 2013, Editor S. Svensson

Several water masses meet and mix off Argentina's northernmost coastline along the Atlantic Ocean. Via the Rio de la Plata estuary, nutrient rich freshwater from the second largest catchment in South America (Piola et al. 2005) empties into the sea and in the south meets the cold water of the Malvinas (Falkland) Current from and in the north the warm water of the Brazil Current (Brandini et al. 2000), creating a potential hotspot for marine wildlife belonging to both subtropical and temperate/subantarctic seas.

The Swedish icebreaker Oden is used for research in the ice-covered areas of the Arctic and Antarctic. In open water she is a slow moving ship that gives excellent opportunity for wildlife observations. On 20 November 2007 the Oden, after having taken bunker in La Plata, was en route to Antarctica between approximately $39^{\circ} 36^{\prime} \mathrm{S}, 57^{\circ} 46^{\prime} \mathrm{W}$ and $39^{\circ} 59^{\prime} \mathrm{S}, 58^{\circ} 11^{\prime} \mathrm{W}$ in the confluence of waters from Rio de la Plata and the Malvinas Current. The weather and sea conditions were extraordinarily favourable for wildlife observations with a totally calm sea with no wind waves and only a very weak swell of approximately $20 \mathrm{~cm}$. Surface salinity and temperature were measured continuously. Generally, salinity increased and temperature decreased from north to south, but with occasional incursions of warmer and more salty water.

Wildlife observations using a pair of handheld binoculars started around 15.00 from vantage points on the foredeck approximately $10 \mathrm{~m}$ above the water or the monkey's island (on top of the bridge) some $30 \mathrm{~m}$ above the water, and continued until darkness made further observations impossible. A summary of the observations is given in Table 1. Counting of absolute numbers of individual species was not possible, and only those individuals that were within distance to allow species identification were counted. Thus, it may appear that larger bird species were more frequent than the smaller species, but this is in part an observational artefact. Also, birds could be identified at a longer distance than the mammals. Species determinations were made using standard identification literature (Carwardine 1995, Harrison 1985, Howell \& Dunn 2007, de la Peña \& Rumboll 1998, Narosky \& Yzurieta 2006, Onley \& Scofield 2007, Reeves et al. 2002, Shirihai \& Jarret 2006). The high pro- 
Table 1. Marine birds and mammals observed in the confluence of the freshwater plume from Rio de la Plata with the salt water from the Malvinas (Falkland) and Brazil currents on 20 November 2007. The numbers observed are scored with different number of plusses: $+1-5,++5-20,+++20-100,++++100-1000,+++++>1000$. Individuals too far off for certain determination are not included in the numbers.

Marina fåglar och däggdjur observerade i sammanflödet mellan sötvatten från Rio de la Plata och saltvatten från Malvinasströmmen den 20 november 2007. Antal plus anger antal enligt ovan.

\begin{tabular}{|c|c|c|}
\hline Species & Score & Note \\
\hline \multicolumn{3}{|l|}{ Birds } \\
\hline Magellanic Penguin Spheniscus magellanicus Magellanpingvin & +++++ & \\
\hline King Penguin Aptenodytes patagonicus Kungspingvin & ++ & \\
\hline Neotropic Cormorant Phalacrocorax brasilianus Sydamerikansk skarv & + & \\
\hline Imperial Shag/King Cormorant Phalacrocorax (atriceps) albiventer Kejsarskarv & ++ & 1 \\
\hline Wandering Albatross Diomedea exulans Vandringsalbatross & + & 2 \\
\hline Yellow-nosed Albatross Thalassarche chlororhynchos Gulnäbbad albatross & + & \\
\hline Black-browed Albatross Thalassarche melanophris Svartbrynad albatross & +++ & \\
\hline Grey-headed Albatross Thalassarche chrysostoma Gråhuvad albatross & + & \\
\hline Antarctic Giant Petrel Macronectes giganteus Sydlig jättestormfågel & + & 3 \\
\hline Hall's Giant Petrel Macronectes halli Nordlig jättestormfågel & + & \\
\hline Great Shearwater Puffinus gravis Större lira & +++++ & 4 \\
\hline Manx's Shearwater Puffinus puffinus Mindre lira & +++++ & \\
\hline Sooty Shearwater Puffinus griseus Grålira & +++++ & \\
\hline Little Shearwater Puffinus assimilis Dvärglira & ++ & 5 \\
\hline Southern Fulmar Fulmarus glacialoides Sydlig stormfågel & ++++ & \\
\hline Cape Petrel Daption capense Brokpetrell & ++ & \\
\hline White-headed Petrel Pterodroma lessonii Vithuvad petrell & + & \\
\hline Atlantic Petrel Pterodroma incerta Vitbukad petrell & ++ & \\
\hline Great-winged Petrel Pterodroma macroptera Långvingad petrel & + & \\
\hline Soft-Plumed Petrel Pterodroma mollis Sammetspetrell & + & \\
\hline White-chinned Petrel Procellaria aequinoctialis Vithakad petrell & ++++ & \\
\hline Spectacled Petrel Procellaria conspicillata Glasögonpetrell & + & \\
\hline Grey Petrel Procellaria cinerea Grå petrell & + & \\
\hline Common Diving-Petrel $\uparrow$ Pelecanoides urinatrix Vanlig dykpetrell & +++ & 6 \\
\hline Blue Petrel Halobaena caerulea Blåpetrell & ++ & \\
\hline Slender-billed Prion Pachyptila belcheri Smalnäbbad valfågel & +++ & \\
\hline Antarctic Prion Pachyptila desolata Antarktisk valfågel & + & \\
\hline Wilsons's Storm-Petrel Oceanites oceanicus Havslöpare & +++ & \\
\hline White-bellied Storm-Petrel Fregetta grallaria Vitmagad stormsvala & ++ & \\
\hline Black-bellied Storm-Petrel Fregetta tropica Svartmagad stormsvala & ++ & \\
\hline White-faced Storm-Petrel Pelagodroma marina Fregattstormsvala & +++ & \\
\hline Grey Phalarope Phalaropus fulicarius Brednäbbad simsnäppa & +++++ & \\
\hline Red-necked Phalarope Phalaropus lobatus Smalnäbbad simsnäppa & +++ & \\
\hline Parasitic Skua Stercorarius parasiticus Kustlabb & ++ & \\
\hline Pomarine Skua Stercorarius pomarinus Bredstjärtad labb & +++ & \\
\hline Long-tailed Skua Stercorarius longicaudus Fjällabb & ++ & \\
\hline South Polar Skua Stercorarius maccormicki Sydpolslabb & + & \\
\hline Kelp Gull Larus dominicanus Dominikanertrut & ++++ & \\
\hline Dolphin Gull Leucophaeus scoresbii Delfinmås & ++ & \\
\hline Arctic tern Sterna paradisaea Silvertärna & +++ & 7 \\
\hline South American Tern Sterna hirundinacea Sydamerikansk tärna & ++ & \\
\hline Royal Tern Sterna maxima Kungstärn & + & \\
\hline
\end{tabular}




\section{Cetaceans}

Fin Whale Balaenoptera physalus Sillval

Sei Whale Balaenoptera borealis Sejval

Bryde's Whale Balaenoptera brydei Brydes fenval

Dwarf/Antarctic Minke Whale Balaenoptera acutorostrata subsp./

B.bonaerensis Dvärg-/antarktisk vikval

Humpback Whale Magaptera novaeangliae Knölval

Pygmy Right Whale Caperea marginata Dvärgrätval

Long-finned Pilot Whale Globicephala melus Långfenad grindval

Dusky dolphin Langenorhynchus obscures Sydlig vitsiding

Risso's Dolphin Grampus griseus Rissos delfin

Spectacled Porpoise Phocoena dioptrica Glasögontumlare

Burmiester's Porpoise Phocoena spinipinnis Svart tumlare

\section{Pinnipeds}

South American Fur Seal Arctocephalus australis Sydamerikansk pälssäl

South American Sea Lion Otaria flavescens Sydamerikanskt sjölejon

Southern Elephant Seal Mirounga leonine Sydlig sjöelefant

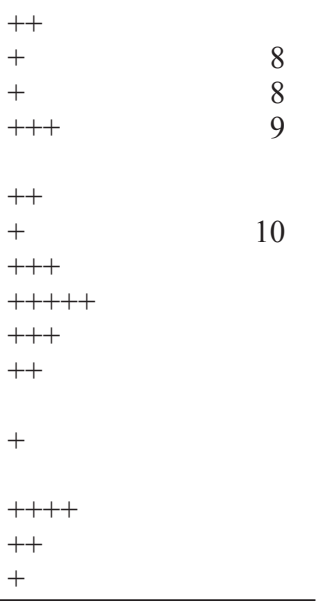

Notes:

1 Species limits unclear. 2 Juveniles only. 3 Juveniles only. At least 30 Giant Petrels were present in total, but only a small fraction could be identified to species. 4 Mostly in large flocks, often in feeding groups associated with cetaceans. 5 The south Atlantic population P. a. elegans sometimes regarded as a separate species Subantarctic Little Shearwater $P$. elegans. 6 This is the most likely species, but other species of Diving-Petrels normally present further south in the Malvinas Current cannot be ruled out. 7 Passage migrant all flying southward; no feeding behaviour observed. 8 Only a couple of individuals were close enough to distinguish between Sei and Bryde's Whale. Additional individuals that could have been either species were present. 9 The distribution areas overlap. No attempt was made to distinguish the two species. 10 Only one individual determined with certainty, but more may have been present.

ductivity of the area was manifest not only by the extremely high species diversity and numbers of individuals and presence of several multispecies feeding groups, but also high levels of chlorophyll and zooplankton in water samples and by the large fleet of fishing vessels active in the area. Additional comments on some species are given below.

Six multispecies feeding groups were seen throughout the area. Dominating these groups were Dusky Dolphins Lagenorhynchus obscurus and Great Shearwaters Puffinus gravis (Figure 1), with other species of birds and cetaceans and South American Fur Seals Arctocephalus australis sometimes joining the fray. The largest feeding group was estimated to consist of some 400 Dusky Dolphins, as many Great Shearwaters, and up to one hundred South American Fur Seals, Longfinned Pilot Whales Globicephala melus, Risso's Dolphins Grampus griseus, two Bryde's Whales Balaenoptera brydei and a Fin Whale B. physalus. It should be noted, however, that none of these species were constrained to the feeding groups, but seen also elsewhere in the area.

The more common species, Magellanic Penguin Spheniscus magellanicus, Great Shearwater, Sooty
Shearwater $P$. griseus, Manx's Shearwater P. puffinus, Wilson's Storm Petrel Oceanites oceanicus, Grey Phalaropes Phalaropus fulicarius, and Kelp Gulls Larus dominicanus were scattered over the entire area. It was noteworthy that the largest bird species, Albatrosses and Giant Petrels, due to the lack of wind were confined to the water's surface and could not avoid harassment by Gulls or Skuas. In one case a Black-browed Albatross Thalassarche melanophris feeding on a dead fish was harassed simultaneously by one Parasitic Stercorarius parasiticus, one Pomarine $S$. pomarinus, and one Long-tailed $S$. longicaudus Skua, before the albatross managed to swim away from the fish. It is also noteworthy that the shape of the bow of the ship, specially designed for ice braking, created an air cushion that smaller bird species would use for "bow-riding" (similarly to when Dolphins ride on a ship's bow wave). This gave excellent opportunity to study species characteristics of for example storm petrels that is usually not possible under more windy conditions.

The most extraordinary observation was that of a feeding Pygmy Right Whale Caprea marginata. Pygmy Right Whales are rarely seen at sea, 

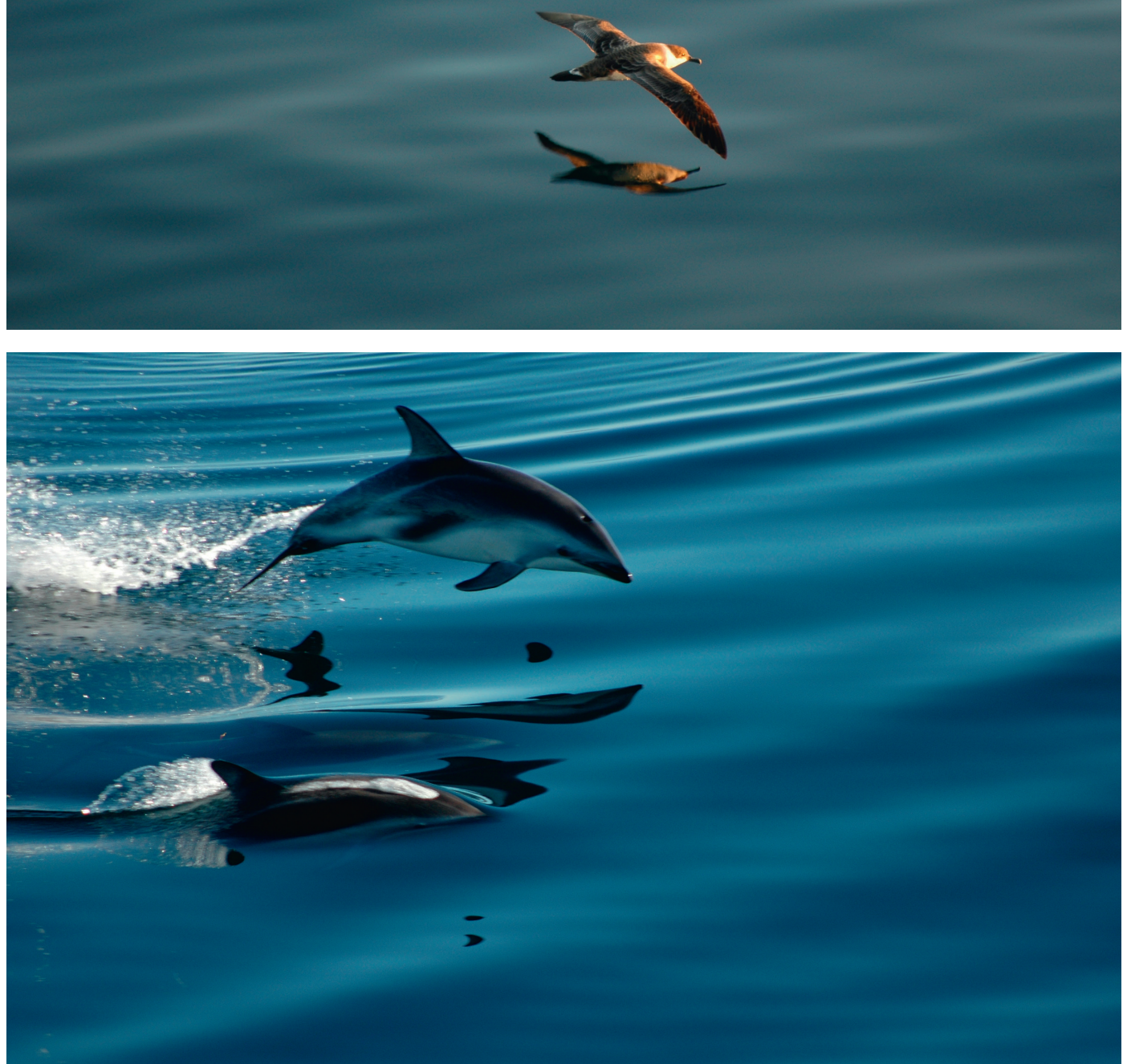

Figure 1. Great Shearwater Puffinus gravis and Dusky Dolphin Langenorhynchus obscures, the most abundant bird and cetacean species. Note the extremely calm sea.

Större lira Puffinus gravis och sydlig vitsiding Langenorhynchus obscurus, den vanligaste fågeln och valen. Notera det spegelblanka havet. 
but several reports come from the sea off northern Argentina (Carwardine 1995). The whale was at the surface for 10-30 seconds and then disappeared under water for 20-50 seconds before it again surfaced, usually less than twenty metres from the point where it was previously observed. The whale was attended by eight Grey Phalaropes, two Slender-billed Prions Pachyptila belcheri, and four Wilson's Storm-Petrels. The birds actively fed around the head of the whale as soon as it surfaced, presumably on zooplankton straining out between the baleen. When the whale dove the birds continued to look for food items while the whale was submerged, but immediately moved to the whale as soon as it surfaced again. A total of 13 dive-cycles were observed.

It is significant that the bird species attracted to the Pygmy Right Whale fed on small zooplankton. Although not much is known about this whale species, copepods have been the main food item in stomachs of the majority of stranded individuals that have been investigated (Best 2007). A couple of Great Shearwaters were attracted to the whale but almost immediately left, presumably due to a lack of suitable food items.

Associations in feeding groups between birds and cetaceans are well known (Evans 1982). These associations mostly consist of several species making use of the same type of food source, such as the fish caught by the dolphins and shearwaters in the large feeding groups observed in the area. However, the birds drawn to the feeding Pygmy Right Whale clearly made use of organisms seeping out between the baleen as the whale pressed water out from the mouth. Similar behaviours are known from birds feeding in the Grey Whale Eschrichtius robusus mud plumes (Obst \& Hunt 1990, Kylin 2013). Pygmy Right Whales are rarely seen alive; most observations are of stranded specimens. To the best of my knowledge this is the first report of birds feeding off food straining out from the whales mouth, and the first time phalaropes have been shown to feed in association with a cetacean.

Bird diversity was also very rich on 16 November as the ship entered the Rio de la Plata plume from the north, i.e. in the confluence of the freshwater with the Brazil Current. However, the weather conditions were less favourable with a low-pressure giving moderately high wind, some rain, partially poor visibility, and a swell of about $3 \mathrm{~m}$, all factors making bird observations difficult and observations of mammals all but impossible. Although many species were seen both in the north and in the south of the freshwater plume, it is not meaningful to make any in-depth comparison. Suffice it to say here that the subtropical species such as Trinidade Petrel Pterodroma arminjoniana and Brown Booby Sula leucogastger were seen north of the plume, but not in colder waters of the south.

\section{Acknowledgements}

George L. Hunt Jr. encouraged the writing of this manuscript. The Swedish Polar Research Secretariat and the officers and crew of IB Oden are thanked for making it possible to work on-board all the way from Sweden to Antarctica, even outside official expedition dates.

\section{References}

Best, P.B. 2007. Whales and Dolphins of the Southern African Subregion. Cambridge University Press, Cambrige.

Brandini, F.P., Boltovskoy, D., Piola, A., Kocmur, S., Röttgers, R., Abreu, P.C. \& Lopes, R.M. 2000. Multiannual trends in fronts and distribution of nutrients and chlorophyll in the southwestern Atlantic (30-60 $\left.{ }^{\circ} \mathrm{S}\right)$. Deep-Sea Research I 47: 1015-1033.

Carwardine, M. 1995. Whales Dolphins and Porpoises. Dorling Kindersley, London.

Evans, P.G.H. 1982. Associations between seabirds and cetaceans: a review. Mammal Review 12: 187-206.

Harrison, P. 1985. Havsfåglar. Wahlström \& Widstrand, Stockholm.

Howell, S.N.G. \& Dunn, J. 2007. Gulls of the Americas. Houghton Mifflin, Boston.

Kylin, H. 2013. Short-tailed Shearwaters Puffinus tenuirostris forage in Grey Whale Eschrichtius robustus mud plumes. Ornis Svecica 23: 114-116.

Narosky, T. \& Yzurieta, D. 2006. Birds of Argentina and Uruguay. Vazquez Mazzini, Buenos Aires.

Obst, B.S. \& Hunt, Jr. G.L. 1990. Marine birds feed at Gray Whale mud plumes in the Bering Sea. Auk 107: 678-688.

Onley, D. \& Scofield, P. 2007. Alabrosses, Petrels and Shearwaters of the World. Helm, London.

de la Peña, M.R. \& Rumboll, M. 1998. Birds of southern South America and Antarctica. Harper Collins, London.

Piola, A.R., Matano, R.P., Palma, E.D., Möller Jr., O.O. \& Campos, E.J.D. 2005. The influence of the Plata River discharge on the western South Atlantic shelf. Geophysical Research Letters 32: L01603 doi:10.1029/2004GL021638

Reeves, R.R., Stewart, B.S., Clapham, P.J. \& Powell, J.A. 2002. Sea mammals of the world. Chanticleer, New York. Shirihai, H. \& Jarret, B. 2006. Whales, Dolphins, and Seals: A Field Guide to the Marine Mammals of the World. A \& C Black, London.

\section{Sammanfattning}

Rio de la Plata är ett stort deltaområde i vilket flera stora floder mynnar. Avrinningsområdet är Sydamerikas näst största. Utanför Rio de la Platas mynning möter det näringsrika sötvattnet den 
kalla Malvinas- (Falklands-) strömmen från söder och den varma Brasilienströmmen från norr. Havet utanför norra Argentina och Uruguay är därför en potentiell mötesplats för marina fåglar och däggdjur från såväl subtropiska som tempererade och subantarktiska vatten som dras till området p.g.a. den höga planktonproduktionen. Under eftermiddagen 20 november 2007 var isbrytaren Oden på väg till Antarktis genom sötvattensplymen söderut. Observationsförhållandena var exceptionellt goda, med stiltje och spegelblankt hav. Totalt sågs 42 fågelarter, elva arter valar, delfiner och tumlare, och tre sälarter. Den mest unika observationen var en födosökande dvärgrätval. Dvärgrätval äter i huvudsak hoppkräftor, och fågelarter som äter samma typ av föda, brednäbbad simsnäppa, smalnäbbade valfågel, och havslöpare, plockade upp smådjur som sipprade ut mellan valens barder då den kom upp till ytan efter dyk. 